This post-print (i.e. final draft post-refereeing) version is archived in accordance with the publisher's policies - see appendix.

The publisher's version is available at http://www.tandfonline.com/doi/pdf/10.1080/01587919.2011.584852

\title{
REPORT
}

\section{Key copyright issues in African distance education: a South African case study}

\author{
Caroline B. Ncube* \\ Department of Commercial Law, University of Cape Town, South Africa \\ (Received 23 October 2010; final version received 2 February 2011)
}

\section{Introduction}

This report draws primarily on the results of the recently concluded African Copyright and Access to Knowledge (ACA2K) Project (see http://www.aca2k.org/), which investigated copyright and access to learning materials in face-to-face, distance education (DE), and dual-mode tertiary educational institutions in Egypt, Ghana, Kenya, Morocco, Mozambique, Senegal, South Africa, and Uganda (Armstrong, de Beer, Kawooya, Prabhala, \& Schonwetter, 2010). The project's main research question was whether copyright laws, policies, and practices in the eight countries maximized access to learning materials. Its research methodology included legal doctrinal review, interviews, document analysis, and comparative analysis of the country findings.

The project found that the copyright laws of these eight countries fail to facilitate meaningful access to learning materials generally and particularly in the DE context (Armstrong et al., 2010, p. 310). The project also found that there is inadequate provision for exceptions in relation to DE. As a result of these inadequacies in the law, and the prevailing socio-economic conditions, copyright law is ignored and access to learning materials is obtained largely through legal infringements (p. 341). Accordingly, the findings suggest that copyright laws be reformed to make them more flexible and appropriate for each African state (p. 342).

Although this report focuses on South Africa, it is worth noting that other developing countries, both within and beyond Africa, appear to face similar issues. For example, similar findings have emerged from research conducted in the Asia Pacific region (Consumers International, 2006).

\footnotetext{
*Email: caroline.ncube@uct.ac.za
} 


\section{DE: needs and practices}

DE providers are responsible for the production or acquisition, collation, and distribution of multiple copies of materials as required by their students; therefore, if any copyright infringement occurs, they are the ones who are likely to be liable. This report thus focuses on institutional concerns. Educational institutions may need to reproduce, translate, adapt, or even convert materials from one format (say, print) to another (say, online or audio) before distributing them or making them available in a library. Generally, most work distributed is in print or printable form, as the costs of Internet access render online distribution beyond the reach of many in Africa (Armstrong et al., 2010, p. 2; Butcher, 2010, p. 2).

Most of the educational materials used and distributed by DE institutions are protected by copyright. To avoid infringing copyright, educational institutions have to systematically review the materials they use to ascertain whether these materials are protected by copyright. If copyright applies, the institution should obtain permission to copy and distribute the material from the copyright holder, unless a statutory exception applies. However, current educational use statutory exceptions do not cater adequately for DE. Therefore, educational institutions should obtain the copyright holder's permission.

The first step in obtaining such copyright permission is establishing the identity and current location of the copyright holder. An educational institution will hold the copyright in material written or created by its employees where this has been agreed in the relevant employment contract or is provided for in applicable institutional intellectual property policies. If the institution or one of its employees does not hold the copyright, it may face significant difficulties in obtaining necessary permissions. This is often a tedious, and ultimately unsuccessful, exercise (George, 2005). Where the copyright holder's rights are administered by a copyright society, such as the Dramatic, Artistic and Literary Rights Organization (DALRO), the institution will have to enter into a licence with the society (see DALRO, 2010).

\section{A brief overview of South African copyright law}

South Africa is bound by the Berne Convention for the Protection of Literary and Artistic work (1886, as amended), and has incorporated the Convention's main provisions into the South African Copyright Act No. 98 of 1978. The Copyright Act provides that literary, musical and artistic works, sound recordings, cinematograph films, broadcasts, programme-carrying signals, published editions, and computer programmes are eligible for copyright protection. There is no need for registration or for the assertion of copyright through statements accompanying the protected work (s. 2, Copyright Act).

Copyright automatically subsists in eligible works if three requirements are met. First, the work must be original, meaning it must not be copied and 'sufficient skill 
and effort' must have been expended in creating it (Dean, 1987, paras. 1-15-1-17; Smith, 1995, p. 9). Second, the work must be reduced to a fixed format such as writing. This requirement does not apply to broadcasts or programme-carrying signals, which must be broadcast or transmitted by satellite, respectively, to be eligible for copyright protection. Third, the creator of the work must be a qualified person or the work must have been first published in South Africa or a Berne Convention country. An individual is so qualified if he/she is a South African citizen or is domiciled or resident in South Africa or a Berne Convention country. Companies and other juristic persons incorporated in South Africa or a Berne Convention country are also so qualified (s. 37 Copyright Act; Copyright Regulations, Notice 136 of 1989 Government Gazette No. 11718 of 3 March 1989). This extension of copyright protection to persons and corporate entities from Berne Convention countries means that South African educational institutions are bound to respect the copyright of materials originating from these other countries.

Copyright holders have exclusive rights in the protected work including reproduction, publication, performance, broadcasting, and adaption (ss. 6-11B, Copyright Act). The term of copyright depends on the nature of the work protected subject to the Berne Convention's provision for a minimum term of the creator's life plus 50 years (ss. 3(2)-3(4), Copyright Act). Exercising any of the copyright holder's exclusive rights without his/her permission or in the absence of a valid statutory exception constitutes copyright infringement. The remedies available to a copyright holder upon infringement of copyright include an interdict prohibiting the infringement, payment of damages or a reasonable royalty, and confiscation of infringing materials from the infringer. Further, the tools used or intended to be used to make infringing works may also be confiscated. Knowingly trading in infringing copies, possessing equipment used to create infringing copies, and performing or broadcasting protected works are also criminal offences (s. 27, Copyright Act).

\section{Fair dealing exceptions}

Fair dealing and fair use are terms that refer to similar, but distinct, statutory concepts that enable use of copyright-protected materials without seeking the permission of the copyright holder under certain circumstances. Fair use is wider than fair dealing because it is not limited to specific uses such as research, study, or criticism (Schonwetter \& Ncube, 2011, p. 67). The USA uses the fair use concept; South Africa uses the fair dealing concept; and some African countries such as Uganda use a hybrid of these two concepts (Armstrong et al., 2010, pp. 322-323; Schonwetter, de Beer, Kawooya, \& Prabhala, 2009, p. 41).

Three fair dealing provisions relate to institutional educational use in the South African Copyright Act, 1978. The first is provided for by section 12(4), which allows the use of a musical or literary work: to the extent justified by the purpose, by way of illustration in any publication, broadcast or sound or visual record for teaching: 
Provided that such use shall be compatible with fair practice and that the source shall be mentioned, as well as the name of the author if it appears on the work. (p. 10) The exception is extended to artistic works, cinematographic films, sound recordings, and broadcasts (ss. 15-18, Copyright Act). However, this exception is ambiguous because it is not clear if it covers both classroom and distance teaching (Rens et al., 2009, p. 9). The same ambiguity is found in Regulation 7 (Copyright Regulations, GNR.2530 of 22 December 1978), which provides only for the making of multiple copies expressly for 'classroom use or discussion.' Therefore, it seems that such fair dealing in DE is precluded (Armstrong et al., 2010, p. 241). One way to adapt this provision to cater for current online learning needs would be to extend classroom to include digital classroom. As this extension may be contested, it would be best secured through legislative amendments. However, such an extension would not resolve the problems facing DE institutions that rely heavily on printed teaching and learning materials. Second, section 12(11) of the Copyright Act provides that translating a work in order to facilitate the first exception is permitted. As the first exception in section 12(4) does not expressly apply to DE, this translation right is, unfortunately, not extended to DE. Third, Regulation 7 permits the making of multiple copies for classroom use, subject to the limit of one copy per student enrolled in the course. Once again, from a DE perspective, the major limitation is the express reference to classroom use. Further, Regulation 7 is subject to Regulation 2 (Copyright Regulations, GNR.2530 of 22 December 1978), which limits the copy to a 'reasonable portion' of the work. This is problematic as it is not clear what would constitute such a portion.

It is worth noting that there are other educational use exceptions that apply to students' uses of literary and musical works for research or private study and for teachers' copying of work for research, teaching, or preparation for teaching in a class. These have not been considered in this report, which focuses on the institutional position. Readers are referred to Rens et al. (2009, pp. 2-3) for consideration of an individual's position.

\section{The need for legislative reform and the role of the Creative Commons licence}

As is evident from the above, current copyright educational use exceptions significantly constrain DE providers. Legislative reforms are required to create exceptions for DE providers to permit archiving, performance, display, digitization, online publication of learning materials, and the creation of multimedia works. In considering such reforms, legislators would do well to learn from the legislation of other jurisdictions, such as the USA's Technology, Education and Copyright Harmonization Act (TEACH Act) of 2002. This Act amended section 110(2) of the US Copyright Act of 1976 by permitting the performance or display of non-dramatic literary and musical works by accredited non-profit educational institutions subject to certain limitations. It also permits digitization of these works (Crews, 2002, 
pp. 5-10; Reyman, 2006, pp. 33-34).

Educational institutions might also benefit from exploring the use of openly licensed educational content (commonly known as open educational resources or OER), as this would bypass current legislative shortcomings. Openly licensed works are either not copyright-protected or are protected using licences that facilitate noncommercial and/or commercial reuse, and sometimes adaptation, without requesting the permission of the copyright holder. Such content can be distributed freely as it is licensed for that very purpose.

In addition to using existing OER, DE institutions may wish to contribute to the educational community by producing more OER. The production of OER by DE institutions would have to be grounded in significant institutional policy and practice shifts, such as establishing the necessary copyright clearance procedures (Hodgkinson-Williams, 2010, p. 2). Where institutions create OER that incorporate copyright-protected material, they will require the permission of the copyright holder to do so. Where such permission is not obtained, the relevant work cannot be included in an OER. Where such work is a critical resource and suitable replacement material cannot be found, the resultant OER may be weakened. If the weak OER is shared online together with other better quality content, this may of course make the institution's open courseware platform an uneven resource (Bazaar Wiki, 2010), which may create marketing problems for the institution. One way to ensure the production of high-quality OER that are not contingent on acquiring copyright permissions is to build OER by incorporating and adapting works that are already openly licensed. There are two main types of open licences to look for when searching for such content: Creative Commons licences and custom licences.

Creative Commons licences are provided free of charge online by Creative Commons, a charitable corporation registered in the USA (http://creativecommons.org) with national branches in many countries including South Africa (http://wiki.creative commons.org/South_Africa). Creative Commons licences are drafted by a team of legal experts in each jurisdiction to ensure that they comply with national copyright laws. These licences many contain any of the following terms (Creative Commons, n.d.): _Attribution: users are allowed to copy, distribute, display, and perform copyrighted work and derivative works based upon it provided they acknowledge the author of the work in the stipulated manner.

_ Share alike: users are only allowed to distribute derivative works under the same terms as the original work was released.

_ Non-commercial: users can only use the original work for non-commercial purposes.

_ No derivative works: users cannot create or share derivative works based on the licensed original work (http://creativecommons.org/about/licenses; see Butcher, 2010, pp. 22-26 for a fuller discussion of these licences). 
Custom licences are used in instances where resources are made available online and permission to distribute the material is given in accompanying copyright statements.

These typically restrict use to scholarly purposes, with citation and without adaptation. By way of example, some institutions affiliated to the Consultative Group for International Agricultural Research (CGIAR), which maintain centres throughout the world, primarily in developing countries, use various kinds of statements, three of which are presented in Table 1.

\begin{tabular}{|l|l|}
\hline Learning material & Licence statement \\
\hline $\begin{array}{l}\text { Business skills for small-scale seed } \\
\text { producers: Handbooks for small-scale } \\
\text { seed producers (Handbook 2) (David \& } \\
\text { Oliver, 2002) }\end{array}$ & $\begin{array}{l}\text { CIAT encourages institutions and } \\
\text { organizations to translate, reproduce or adapt } \\
\text { this publication. Please send information on } \\
\text { the translation, reproduction and adaptation } \\
\text { of this publication to . . Copies of } \\
\text { illustrations can be obtained upon request } \\
\text { from the same address. (p. ii) }\end{array}$ \\
\hline $\begin{array}{l}\text { Fodder for a better future: How agroforestry } \\
\text { is helping to transform the lives of } \\
\text { smallholder dairy farmers in East Africa } \\
\text { (Pye-Smith, 2010) }\end{array}$ & $\begin{array}{l}\text { This booklet may be quoted or reproduced } \\
\text { without charge, provided the source is } \\
\text { acknowledged. No use of this publication } \\
\text { may be made for resale or other commercial } \\
\text { purposes. (p. ii) }\end{array}$ \\
\hline $\begin{array}{l}\text { Price, inventories, and volatility in the global } \\
\text { wheat market (Pietola, Liu, \& Robles, } \\
2010)\end{array}$ & $\begin{array}{l}\text { Sections of this material may be reproduced } \\
\text { for personal and not-for-profit use without } \\
\text { the express written permission of but with } \\
\text { acknowledgment to IFPRI. To reproduce the } \\
\text { material contained herein for profit or } \\
\text { commercial use requires express written } \\
\text { permission. (p. ii) }\end{array}$ \\
\hline
\end{tabular}

Table 1 Examples of copyright permissions

Custom licences can be ambiguous. For example, in the third statement above, no indication is given of the extent of the sections that may be reproduced. Other legal challenges may arise in drafting custom licences (Butcher, 2010, p. 22), such as ensuring enforceability and integrity of the licence. Therefore, it may be more prudent to use one of the Creative Commons licences, as these have been drafted by copyright experts, are standardized, and have gained much credibility and currency worldwide.

\section{Conclusion}

Copyright law currently raises major issues for DE provision in South Africa, as it does not adequately cater for institutional needs. These issues include the costs and administrative overheads attendant on acquiring copyright permissions and the compromised quality of course materials where institutions are unable to obtain requisite copyright permissions. National legislative reforms are required to create 
meaningful educational use exceptions that permit multiple reproductions, archiving, performance, display, digitization, online publication, and the compilation of multimedia works. These reforms must be within the confines of binding international agreements. As legislative reforms are often long in the making, educational institutions might consider relying on and producing more OER while taking the necessary care to avoid copyright infringement. To achieve this, DE providers with limited expertise, funds, and resources may need to rely on support from organizations such as the South African Institute for Distance Education, through its OER Africa Initiative, UNESCO, and the Commonwealth of Learning.

\section{Notes on contributor}

Caroline Ncube is a senior lecturer at the University of Cape Town. She was a researcher in the African Copyright and Access to Knowledge Project.

\section{References}

- African Copyright and Access to Knowledge (ACA2K) Project. (n.d). Retrieved from http://www.aca2k.org/

- Armstrong, C., de Beer, J., Kawooya, D., Prabhala, A., \& Schonwetter, T. (Eds.). (2010). Access to knowledge in Africa: The role of copyright. Cape Town: UCT Press.

- Bazaar Wiki. (2010). Open courseware. Retrieved from http://wiki.bazaar.org/index.php/Open_Courseware

- Berne Convention for the Protection of Literary \& Artistic Works, 9 September 1886, as amended 28 September 1979.1161 UNTS 3.

- Butcher, N. (2010). OER dossier: Open educational resources and higher education. Paper presented at the Workshop for Heads of Commonwealth Universities, Cape Town. Retrieved from http://www.col.org/SiteCollectionDocuments/OER_Open_Educational_Resources_and_ Higher_Education.pdf

- Commonwealth of Learning. (n.d.). Retrieved from http://www.col.org

- Consumers International. (2006). Copyright and access to knowledge: Policy recommendations on flexibilities in copyright laws. Kuala Lumpur: Consumers International. Retrieved from http://www.consumersinternational.org/media/303356/copyright $\% 20$ and $\%$ 20access $\% 20$ to $\% 20$ knowledge $\% 20-\% 20$ full\%20report\%20(pdf).pdf

- Copyright Regulations, GNR.2530 of 22 December 1978 (1978).

- Copyright Regulations, Notice 136 of 1989 Government Gazette No. 11718 of 3 March 1989 (1989).

- Creative Commons. (n.d.). About the licenses. Retrieved from http://creativecommons.org/about/licenses

- Creative Commons South Africa. (n.d.). Retrieved from http://za.creativecommons.org

- Crews, K.D. (2002). New copyright law for distance education: The meaning and importance of the TEACH Act. Retrieved from http://www.ala.org/Template.cfm?Section=distanceed\&Template=/ContentManageme nt/ContentDisplay.cfm\&ContentID=25939

- David, S., \& Oliver, B. (2002). Business skills for small-scale seed producers: Handbook two. Kampala: International Center for Tropical Agriculture (CIAT). Retrieved from http://isa.ciat.cgiar.org/catalogo/listado_tools.jsp?pager.offset=20\&tema=AGROENTER PRISES

- Dean, O.H. (1987). Handbook of South African copyright law. Cape Town: Juta. 
- Dramatic, Artistic and Literary Rights Organization (DALRO). (2010). Reprographic reproduction rights. Johannesburg: Author. Retrieved from http://www.dalro.co.za

- George, C.A. (2005). Testing the barriers to digital libraries: A study seeking copyright permission to digitize published works. New Library World, 106, 332-342. doi: 10.1108/0307480 0510608648

- Hodgkinson-Williams, C. (2010). Institutional report 2: Sketching the terrain: Open educational resources for teaching and learning at the University of Cape Town. Cape Town: University of Cape Town. Retrieved from http://www.cet.uct.ac.za/files/os\%20institutional\%20Report\%202.pdf

- Pietola, K., Liu, X., \& Robles, M. (2010). Price, inventories, and volatility in the global wheat market (IFPRI Discussion Paper 00996). Washington, DC: International Food Policy Research Institute. Retrieved from http://www.ifpri.org/publication/priceinventoriesand- volatility-global-wheat-market

- Pye-Smith, C. (2010). Fodder for a better future: How agroforestry is helping to transform the lives of smallholder dairy farmers in East Africa (ICRAF Trees for Change No. 6), Nairobi: World Agroforestry Centre. Retrieved from http://www.worldagroforestry.org/downloads/publications/PDFs/B16723.PDF

- $\quad$ Rens, A., Chetty, P., Schonwetter, T., Khan, R., Jacobson, P., \& Maistry, U. (2009). Report on South African open copyright review. Cape Town: Shuttleworth Foundation.

- Reyman, J. (2006). Copyright, distance education, and the TEACH Act: Implications for teaching writing. College Composition and Communication, 58, 30-45.

- Schonwetter, T., de Beer, J., Kawooya, D., \& Prabhala, A. (2009). Copyright and education: Lessons on African copyright and access to knowledge. African Journal of Information and Communication, 10, 37-52.

- Schonwetter, T., \& Ncube C. (2010). New hope for Africa? Copyright and access to knowledge in the digital age. Paper presented at CPR Africa Conference, Cape Town. Retrieved from http://uctipunit.files.wordpress.com/2010/07/cprafrica_paper_tscn110410.pdf

- Smith, A. (1995). Copyright companion. Durban: Butterworths.

- South African Copyright Act No. 98 of 1978 (1978). 


\section{Search - Publisher copyright policies \& self- archiving}

One journal found when searched for: distance education

Journal: Distance Education (ISSN: 0158-7919, ESSN: 1475-0198)

RoMEO: This is a RoMEO green journal

Paid OA: A paid open access option is available for this journal.

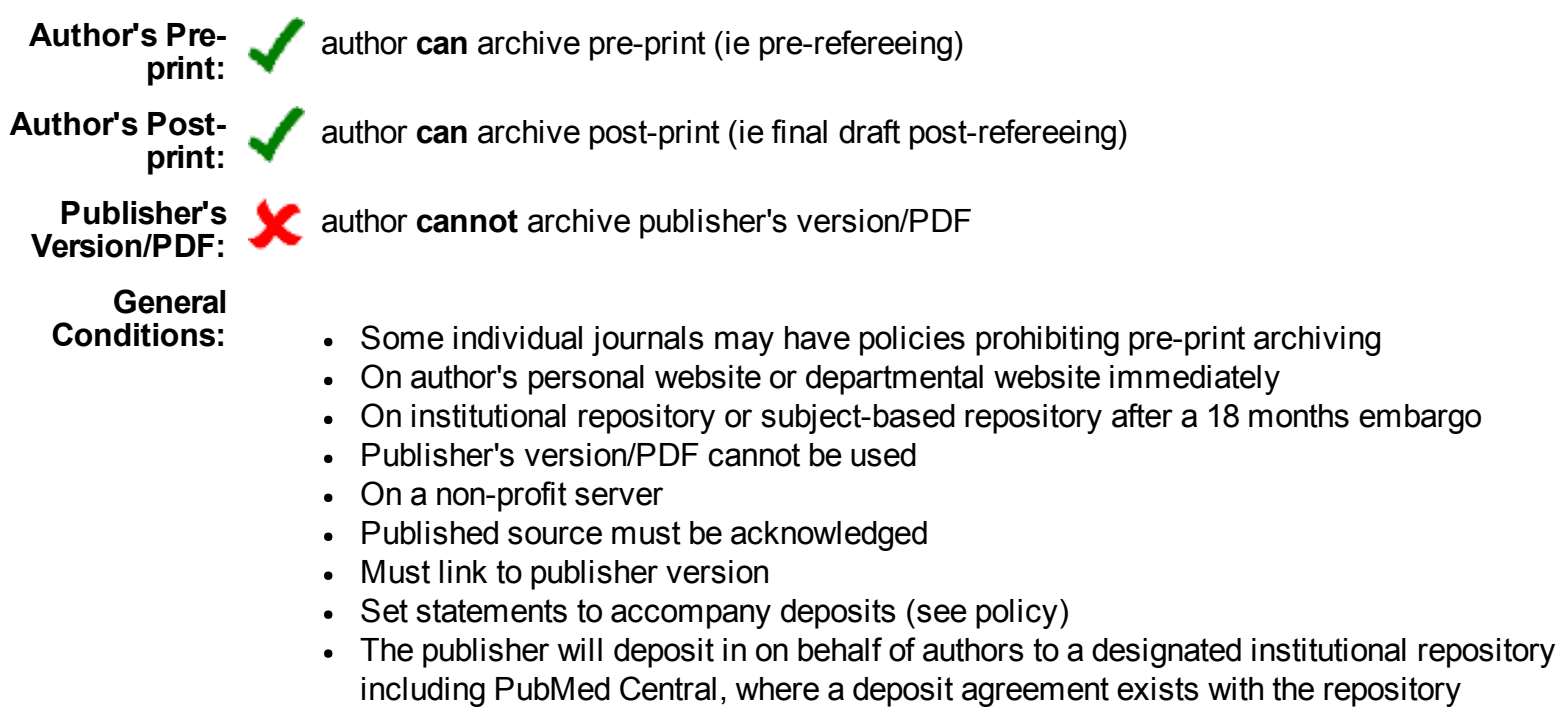

Mandated OA: (Awaiting information)

Paid Open Routledge Open Select

Access:

Notes:

- SSH: Social Science and Humanities

- Publisher last contacted on 25/03/2014

Copyright: Policy

Updated: 26-Mar-2014 - Suggest an update for this record

Link to this http://sherpa.ac.uk/romeo/issn/0158-7919/

page:

Published by: Taylor \& Francis (Routledge): SSH Titles [Commercial Publisher] - Green Policies in ROMEO

For: Open and Distance Learning Association of Australia (ODLAA) [Client Organisation] Suggest to ROMEO

Guidance: Please see the list of Publisher Categories in RoMEO for guidance on interpreting the priority of multiple publishers.

These summaries are for the journal's default policies, and changes or exceptions can often be negotiated by authors.

All information is correct to the best of our knowledge but should not be relied upon for legal advice. 


$\begin{array}{cl}\text { Green } & \begin{array}{l}\text { Can archive pre-print and post-print or } \\ \text { publisher's version/PDF }\end{array} \\ \underline{\text { Blue }} \quad \begin{array}{l}\text { Can archive post-print (ie final draft post- } \\ \text { refereeing) or publisher's version/PDF }\end{array} \\ \underline{\text { Yellow }} \quad \begin{array}{l}\text { Can archive pre-print (ie pre-refereeing) } \\ \text { White }\end{array} \quad \begin{array}{c}\text { Archiving not formally supported } \\ \text { or }\end{array} \quad \underline{\text { Miew all publishers on colours and restrictions }}\end{array}$

Use this site to find a summary of permissions that are normally given as part of each publisher's copyright transfer agreement.

The RoMEO Journals database is supplemented with information kindly provided by:

- the British Library's Zetoc service hosted by MIMAS,

- the Directory of Open Access Journals (DOAJ) managed by Infrastructure Services for Open

Access,

- the Entrez journal list hosted by the NCBI.

(C) 2006-2016, University of Nottingham

$\underline{\text { Contact us }}$ 